\title{
THE CASE OF A HERO: DEHEROIZED STORY MODEL AND NEW PROCESSES OF IDENTIFICATION IN THE EARLY BOSNIAN-HERZEGOVINIAN SHORT STORY
}

Anisa Avdagić1

Faculty of Philosophy, University of Tuzla

Received: 20.06.2011

UDC: $821.163 .41 / .43(497.6) .09-32$

Accepted: 04.11.2011

\begin{abstract}
This work discusses the short story by Svetozar Ćorović Mujagino junaštvo (Mujaga's Heroism) as an example of the narrative transition onto a deheroized model of a historical story which relates to a different concept of history, and different processes of identification.
\end{abstract}

Key words: deheroized story model, biographical narrative, identity, identification

\section{INTRODUCTION}

Narrative focus on individual life is nothing special in Bosnian-Herzegovinian short story, not even in the early ${ }^{2}$ Bosnian-Herzegovinian short story from the beginning of the $20^{\text {th }}$ century which is hugely absorbed with collective identity. However, different from the most narrative examples in which the practice of portraying the life of the individual retains its ideological function, and the ending is stylized by a clear (moral) message, the narrative which Zdenko Lešić in his study Pripovjedačka Bosna names the biographical, ,shapes the fate of the individual by presenting it as existence in time whose sense evades the unique attribute“" (Lešić, 1991, p. 93).

\section{Correspodence to:}

Anisa Avdagić, Faculty of Philosophy, University of Tuzla

Tihomila Markovića 1, Tuzla. B\&H.

Phone: +387 61734336

E-mail: anisa.avdagic@untz.ba

2 The term "early" (story) is used because of the fact that the Bosnian-Herzegovinian short story got its first public form at the end of the $19^{\text {th }}$ and beginning of the $20^{\text {th }}$ century, during the Austro-Hungarian rule in Bosnia and Herzegovina, when it was given enough space in the new magazines.
This evasion of the unique attribute and sense presents the biographical narrative as the basic transitional cultural genre at that time, since „,not only is the disassociation of the modern and traditional order of cultural and social values taking place, but also the process of Europeanization of the Bosnian-Herzegovinian culture and the whole society in the age of the Austro-Hungarian rule" (Kazaz, 2008, p. 158). 
Firstly, the biographical narrative meant „disassociation of the culture defined by the epic cultural code and with it coordinated heroic cultural paradigm and crossing over onto the deheroized model of the historical story and with it coordinated historical memory“ (Kazaz, 2008, 158).

Serious disassociation from the culture defined by the epic code can already be read in some short stories by Svetozar Ćorović gathered into the collection Priče iz nemirnih vremena. Ćorović's narrator, who is in a defeatist mood, does not seize exactly for huge events in any sense. Considering the changed content of culture and the lack of the ingrained construct of heroism, Ćorović's narrator is searching for the possibility of a different motivational and identification framework. Namely, the narrator uses small, individual truths to reflect troubled times, but not to write existential meaning into those times. On the contrary, the narrator represents troubled times in order to show how these times devastate human existence, and largely bring distress on people. On the other hand, he gives his characters the opportunity to articulate, outside official historiography and epic propositions, their elementary human qualities which others can relate to.

In other words, Ćorović's stories like e.g. Mujagino junaštvo (Mujaga's Heroism) start with new, different processes of identification which are based on the representation of individual truths, the care for each individual life, demanding, or offering, a space for solidarity and loyalty. Mujaga, the main character of Ćorović's story, is neither ashamed to admit that he went to war only when he was put under pressure, nor is he ashamed to admit that he bitterly wept and (as much as possible) evaded every war encounter, thus deconstructing the epic construct of heroism:
What heroes? There are no heroes - he said abruptly. - Everyone is a hero when he becomes tired of it. If you are surrounded, you have to defend yourself; if you defend yourself well, you are a hero. If you see someone who is weaker than you, and you chase him and kill him - you are a hero! Even a cat is a hero when you fall upon her, and a cat is a hero when it falls upon a mouse... I do not know of other heroes (Ćorović, 1967, p. 31).

Mujaga's heroism, from its title, is not subject to irony by the narrator (even the sneer of Mujaga's listener, the collocutor is discouraged). On the contrary, it opposes the ideological machines of epic culture with the norm of the honest humanity which will not be based on other people's death, weakness and impossibility (as a construct of epic heroism is based on). The story, therefore, vicariously treats the origin of epic glory.

Mujaga is haunted by the death of another man and he cannot find the possibility for justifying it or aesthetization of it (the institutions doing this are being questioned as well), just as he cannot find the possibility for himself to transcend the horrible concept of pity.

I'm haunted by that apparition; haunted without rest. I even went to the mullah, told him everything and asked for a charm... Still nothing... Mullah wanted to encourage me and started talking. „You are a hero“, he said, „Because you killed a Vlach“... "But I'm not a hero“, I said, ,I'm a sinful man, in front of whom God will close the gate of heaven and send me to hell“"..., ,Another man would boast of that", he said again... „May someone else boast of it, I won't“", I shot back; ,I am not a hero. I am only Mujaga, even Arshinagha, if you want, but I'm not a hero. To kill a man and be a hero, is it?"“(Ćorović, 1967, p. 33). 
Since the reductionist field of heroic fame does not allow for individual weakness and arrest, the story, contrary to the ideological power and life organization based on epic measures, represents priority of a different authority from the other side. In other words, the story represents the ethics of godliness as a conciliatory and basic human quality, since lacking other possibilities of recognizing values, this ethics of godliness is equal to the ethics of caring according to which the experience of others can be imagined (even experienced) as one's own.

I killed a man, and I had never seen him before!... I killed him and burdened my soul with sin like no one in my family... God gave man life; I took it, as if I spoil God's work... I a maggot, to order the world better than God ordered it... What am I to do with that calamity? (Ćorović, 1967, p. 33).

However, represented godliness, humility and care cannot and must not have an intermediary and interpreter to the fictive authority. In that name, the story takes on the process of re-humanization; grounding as opposite to the creation of hero or epic height; and thus questions efficiency, meaningfulness of the epic ideal (according to which the enemy has to be killed):

If I had killed him, - he added - I would have aggrieved his wife and five children. (...) So tell me where my soul would go?... How would I justify myself with God? How?... (Ćorović, 1967, p. 36).

In search of a new concept of life, for a more authentic existence, Ćorović's hero begins his own history different from the one which is nurtured by his community through different institutions. Reacting to the processes of naturalizing historical necessities, he creates a new reality which distances him from the collective, represents as an individual and (although still feebly) tries to defend the possibility of the right for a subjective experience of life and human quality in it. Thus, Mujaga's inadaptability to the collective/epic propositions in the story is not an example of individual estrangement which is used to look for a way of amortization or annulment, but a sign of vulgarity of the system of power. Corović's story Mujagino junaštvo interesting also because an individual himself, and from the very beginning, raises the consciousness and represents the new concept of life, and alternative historical memory along with it. Namely, in the context of BosnianHerzegovinian short story, and also in the wider South Slavic context, there are paradigmatic stories which represent the disfunctionality of the culture defined by the epic cultural code, and individual trouble in the cleft or shift of cultures - e.g. Put Alije Đerzeleza by Ivo Andrić, Hadžijin mač by Hamza Humo or Marko Kraljević po drugi put među Srbima by Radoje Domanović. In that sense, Andrew B. Wachtel in the study Stvaranje nacije, razaranje nacije considers Domanović's, and later even Andrić's story as a great example of cultural shock, because the reading audience is gradually imposed on with understanding that excessive identification (of the characters, and the audience) with the heroic ethos presented in the folk songs „is not a suitable basis for the twentieth century South Slavic culture and society" (Vahtel, 2001, p. 74). Ćorović's story thus fits into a wider scope of interest for individual life or the relationship between the community and the individual. It could also be said that it appears as the first step towards that sphere. 
However, in Andrić's, Domanović's or Humo's story, the historical/political context is what undoubtedly dictates the disassociation from a culture marked by the epic code; historical context defines the allochrony of such a culture and such action. Mujaga's agency, though, is represented in a somewhat different way.

Corović's narrator gives the individual the possibility of the recreation of the world, while Humo, and especially Andrić in written raise awareness of the fact that even these fantasies have already been constituted by the outer and that the conditions of all possibilities are in the outer/ the contextual. That is why e.g. Đerzelez does not have a chance for the restoration of the old world or confirming its values in new historical circumstances.

Therefore, apart from the fact that Ćorović's story is not about excessive identification with the obsolete ideals of the epic, but the consciously distancing of the individual from common ideals with which he does not find the possibility of identification (although the collective still lives under the epic coercion). A special difference lies in the fact that Ćorović's narrator does not allow the ironizing or questioning of Mujaga's version of heroism - the act of creating a new world. The storyteller undoubtedly qualifies his hero as an acknowledged being, bearing in mind the fact that Mujaga overcomes the implicit social norms, and thus the question of power. It is an amazing step in positioning the individual along the collective.

Mujagino junaštvo (Mujaga's Heroism) is an example of an early story (published in 1905) which reflects humanistic commitment, a commitment to the individual within the strict collective order. In the context of Bosnian-Herzegovinian short story, this story model will be developed for a long time, and with a different organization of the text, it will be considered actual even today. Mujaga's action and the distance he takes, opens a space of livability $^{3}$ out of the collective norms, while the space of livability in iterative acts has a chance for its own standardization.

\section{REFERENCES}

- Butler, J. (2005[2004]). Raščinjavanje roda [Undoing gender]. Sarajevo, B\&H: Šahinpašić.

- Ćorović, S. (1967). Sabrana djela (Priče iz nemirnih vremena), knjiga VIII [Collected stories - The story of unsettled times, book VIII]. Sarajevo, B\&H: Svjetlost.

- Kazaz, E. (2008). Neprijatelj ili susjed u kući [The enemy or neighbor in the house]. Sarajevo, B\&H: Rabic.

- Lešić, Z. (1991). Pripovjedačka Bosna I [Storytelling Bosnia I]. Sarajevo, B\&H: Svjetlost - Institut za književnost.

- Vahtel, E. B. (2001[1998]). Stvaranje nacije, razaranje nacije [Making a nation, breaking a nation ]. Belgrade, Serbia: Stubovi kulture.

3 The concept of livability which marks the ability or capacity of someone or something to live was taken from Judith Butler. Given the fact that the gender regimes of which J. Butler speaks are in a polyvalent relation with all forms of antagonism, this concept seems acceptable, furthermore, needed in understanding the identification processes represented in this text. See Butler (2005). 